\title{
Matematik Öğretmenlerinin Ara Disiplinlere İlişkin Görüşleri
}

\section{The Opinions of Maths Teachers Concerning Cross Curriculum Disciplines}

Şule AKYOL*

Öz: Bu araştırmanın amacı 6-7-8. sınıf matematik dersi öğretim programında yer alan ara disiplinlere yönelik öğretmen görüşlerini belirlemektir. Çalışma ile 2005 yılında uygulamaya koyulan matematik dersi öğretim programında yer alan ara disiplinlerden öğretmenlerin haberdar olma düzeyleri ve ara disiplinleri işe koşma durumları ortaya çıkarılmıştır. Araştırmanın çalışma grubunu Burdur'da 6-7-8. sinıflarda görev yapan 12 matematik öğretmeni oluşturmuştur. Araştırmada nitel araştırma yöntemi kullanılmış, veriler görüş̧e tekniği ile elde edilmiş ve betimsel analizle çözümlenmiştir. Araştırmada elde edilen bulgulara göre öğretmenlerin ara disiplinler konusunda çok az ve sınırlı bilgiye sahip olduğu sonucuna ulaşılmıştır. Öğretmenler programın yoğun olması, zaman sıkıntısı, öğrencilerdeki sınav kaygıSı ve programı yetiştirme telaşı gibi sebeplerden dolayı ara disiplinlere derslerinde çok fazla yer veremediklerini belirtmişlerdir. Öğretmenlerin çoğu ara disiplinlerin önemli ve gerekli olduğunu düşünmektedir; öğretim programı hafifletilirse, süre sıkıntısı ortadan kaldırılırsa ve ara disiplinler konusunda gerekli bilgilendirmeler yapılırsa, derslerinde ara disiplinleri işe koşabileceklerini söylemişlerdir. Çalışmanın sonunda uygulamaya yönelik bazı önerilere yer verilmiştir.

Anahtar sözcükler: Ara Disiplinler, Matematik Öğretmenleri, Matematik Dersi Öğretim Programı, Görüşme

Abstract: The aim of this study was to determine maths teachers' opinions concerning the cross curriculum approach which forms a part of $6^{\text {th }}, 7^{\text {th }}$ and $8^{\text {th }}$ grade maths curriculum. With this study, the maths teachers' awareness level and utilising the situation of cross curriculum in the maths curriculum that was put into practice in 2005 was determined. The group studied consisted of 12 maths teachers who work in the $6^{\text {th }}, 7^{\text {th }}$ and $8^{\text {th }}$ grade in Burdur. In this study the qualitative method was employed with data gathered through the interview technique and analysed by the descriptive method. From these results it was determined that the math teachers have too low and limited knowledge concerning cross curriculum disciplines. The teachers said that they didn't give enough time to cross curriculum disciplines in the course of their lessons due to the intensity of the curriculum, the lack of time, the exam anxiety of the students and the teachers' hurry to finish. Most of the teachers do think that cross curriculum disciplines are important and necessary. The teachers said that they can apply cross curriculum disciplines in their lesson, if the curriculum can be altered, if the time-table was less restricting and confining and if information about cross curriculum disciplines can be given. At the end of study, some suggestions were made to implement the practice.

Keywords: Cross Curriculum Disciplines, Maths Teachers, Maths Curriculum, Interview

\footnotetext{
*Arş. Gör., Mehmet Akif Ersoy Üniversitesi, Eğitim Fakültesi, Eğitim Bilimleri Bölümü, Burdur. akyolsule@gmail.com $\mathrm{Bu}$ çalışma Yüksek Lisans tezinin bir bölümünden üretilmiştir.
} 


\section{Giriş}

Ara disiplinler, program hazırlama sürecinde göz önünde bulundurulan ana disiplinlerle açık ve kapsayıcı biçimde örtüşen diğer disiplinler olarak tanımlanmıştır (ERG 2005, 118). Ara disiplinler, ilköğretim matematik dersi öğretim programı ile ilișkilendirilmiş, bütün programlarda yer alan ve ortak olarak kazandırılması gereken özelliklerdir (Akyol 2011). Matematik öğretim programının kazanımlarıyla ilişsilendirilen 8 ara disiplin bulunmaktadır. Bunlar; Sa ğlık Kültürü̈, İnsan Hakları ve Vatandaşlık, Girişimcilik, Kariyer Bilinci Geliştirme, Rehberlik ve Psikolojik Danışma, Spor Kültürü ve Olimpik Eğitim, Afetten Korunma ve Güvenli Yaşam ve Özel Eğitimdir.

Ara disiplin temaları; bilginin belirli bir alana veya disipline hapsedilmemesini, aralarında ilişkilendirilmesini gerektirmektedir (Naval et al. 2003). Örneğin İspanya'da ara disiplinler; vatandaş ve değer eğitimi, barış eğitimi, sağlık eğitimi, cinsiyetler arasında firsatlar eşitliği eğitimi, çevre eğitimi, cinsiyet eğitimi, tüketici eğitimi ve trafik eğitimini içermektedir (Naval et al. 2003).

Ara disiplin temaları, sosyal taleplere veya konulara cevap vermektedir. Okulun sosyal içeriğinde rastlanılan sosyal problemleri göstermektedir, böylece okulun sosyalleştirme fonksiyonunu güçlendirmektedir. Ek olarak ara disiplin temaları, ülke insanlarının günlük yaşamına değindikçe, kaçınılmaz bir şekilde daha özgür, barışçıl ve doğal çevre konusunda daha sorumlu insanlarla dolu toplumun yapısını inşa edecektir (Naval et al. 2003). Özet olarak ara disiplin temaları; toplumun ve öğrencilerin hayati tecrübelerinden ortaya çıkmaktadır, çevreyle ilgili sosyal taleplere cevap vermektedir, günlük hayattaki zıtlıkları içeren kritik davranışları teşvik etmektedir, programın gizli (örtük) kısmına ait açıklığı içermektedir ve bireylerin gelişimini tamamlamaya katkıda bulunmaktadır (Naval et al. 2003).

Ara disiplinler sayesinde öğrenciler;

1) Başkalarının ve kendilerinin sorumluluğunu ve değerini öğrenmektedir.

2) Toplumdaki insanların dayanışmasını anlamaktadır.

3) Fiziksel, ruhsal, sosyal potansiyellerini başararak; kendini bilme ve özsaygılarını geliştirmektedir.

4) Yetişkin bireyler olarak; anlayış ve bilgilerini ve diğer güçlü yönlerini ve sınırlarını, kişisel özelliğini, ilgilerini, yeteneklerini, becerilerini, potansiyelini, değerlerini, motivasyon ve ihtiyaçlarını geliştirmektedir (DENI 2008).

Matematik programına ara disiplinler yerleştirilerek kazanımlar zenginleştirilmiş, öğrencilerin korkulu rüyası olan matematik dersi yaşamla ve bazı belirlenen alanlarla ilişkilendirilerek tek bir disiplin olarak sıkışıp kalması engellenmek istenmiştir (Akyol 2011). Milli Eğitim Bakanlığ (MEB 2009), matematik dersi 6-8. sınıf öğretim programı ve kılavuzunda 'ilişkilendirme önemsenmelidir' başlığ 1 altında ara disiplinlerin programa yerleştirilmesinin sebebini şu şekilde ifade etmiştir: "Matematik bilgilerinin, hem gerçek hayatla hem de diğer derslerde ögrenilenlerle ilişkilendirilmesine önem verilmelidir. Günlük yaşamda, birçok durumda çeşitli zorluk derecelerinde matematiğe ait problemler karşımıza çıkmakta ve matematik pek çok meslek dalında kullanilmaktadır. Bu nedenle problemler, öğrencilerin matematiğin günlük hayattaki kullanımını açık biçimde görmelerine yardımcı olacak şekilde seçilmelidir. Öğrenciler matematiğin diğer derslerde de kullanılabildiğini gördüklerinde, kazanımları daha anlamlı olacaktır. Bu amaçla matematik dersi belli başlı ara disiplinlerle iliş̧kilendirilmiştir’. MEB aynı yerde, etkinlikler planlanırken ve yürütülürken alt öğrenme alanlarındaki kazanımlar ile ara disiplinlerin kazanımlarının aynı anda edinilmesine dikkat edilmesi gerektiğini belirtmiştir.

2005 'te uygulamaya koyulan yeni ilköğretim programlarının gerek ders içi, gerekse diğer derslerle ve ara disiplinlerle ilişkilendirmeler boyutlarında önceki programlara göre önemli 
ölçüde değişim gösterdiği görülmüştür. Bu değişimin programın uygulayıc1ları olan öğretmenler tarafından ne derece benimsendiği ve uygulamaya konduğu incelenmesi gereken bir durumdur (Coşkun \& Demirel 2009). Yağc1, Demirel ve Tatar (2009), ara disiplinlerle bütünleştirilmesi amacıyla programlarda yapılan düzenlemelerin olumlu bir girişim olduğunu, ancak programların asıl uygulayıcıları olan öğretmenlerin yaşadığı sorunların dikkate alınarak gerekli düzenlemelerin yapılması gerekmekte olduğunu vurgulamıştır.

\section{Araştırmanın Amacı}

$\mathrm{Bu}$ araştırmada 6-7-8. sınıf matematik dersi öğretim programında yer alan ara disiplinlere ilişkin öğretmen görüşlerini belirlemek ve elde edilen bulgular 1şığında yorum yapmak ve öneriler sunmak hedeflenmiştir. Araştırma, matematik öğretmenlerinin ara disiplinlerden haberdar olma düzeyini ve ara disiplinleri işe koşma durumlarını ortaya çıkarması açısından önemlidir. Çalışmada şu alt probleme yanıt aranmıştır:

Matematik öğretmenlerinin 6-7- 8. sınıflar matematik dersi öğretim programında yer alan ara disiplinlere yönelik görüşleri nelerdir?

\section{Yöntem}

\section{Araştırma Modeli}

Araştırmada öğretmenlerin görüşlerini belirlemek amacıyla algıların ve olayların doğal bir ortamda gerçekçi ve bütüncül bir şekilde daha derinlemesine ortaya konmasını sağlayan nitel araştırma yöntemi kullanılmıştır.

Araştırma, nitel araştırma deseni olan olgu bilim deseninde yapılmıştır. Bu desende bireylerin bir olguya ilişkin yaşantılarını, algılarını ve bunlara yüklediği anlamları ortaya çıkarmak amaçlanmaktadır (Yıldırım \& Şimşek 2008). Araştırmada incelenen olgu ara disiplinlerdir.

\section{Çalışma Grubu}

Araştırmanın çalışma grubunu 9 kadın (\%75), 3 erkek (\%25) olmak üzere toplam 12 matematik öğretmeni oluşturmaktadır. Görüşme yapılacak öğretmenler okulların ortaöğretime yerleştirme puanı (OYP) ortalamalarına göre başarı sıralarına bakılarak oluşturulan üst, orta ve alt guruptan seçilmiştir. Araştırmada amaçsal örnekleme yöntemlerinden tabakalı amaçsal örnekleme kullanılmıştır.

\section{Veri Toplama Araci}

Araştırmada veri toplama yöntemi olarak görüşme kullanılmıştır. Öğretmenlerin görüşleri görüşme formu ile elde edilmiştir. Görüşme formunda 10 soru yer almaktadır. Görüşme formunun kapsam geçerliğini sağlamak için sekiz uzmandan görüş alınarak forma nihai şekli verilmiş ve form uygulamaya hazır hale getirilmiştir. Ayrıca araştırma kapsamı dışında bırakılan iki öğretmen ile ön görüşme yapılmıştır.

\section{Verilerin Analizi}

Görüşme esnasında elde edilen veriler gönüllülük esasına dayanarak, ses kayıt cihazıyla kaydedilmiştir. Daha sonra elde edilen veriler yazılı metin haline çevrilmiştir. Veriler betimsel analiz ile çözümlenmiştir. Betimsel analiz yaklaşımı, verilerin araştırma sorularının ortaya koyduğu temalara göre organize edilmesini ve görüşmede kullanılan sorular dikkate alınarak sunulmasını sağlamaktadır (Yıldırım \& Şimşek 2008).

Betimsel analiz doğrultusunda görüşme soruları dikkate alınarak tematik çerçeve oluşturulmuş, araştırmaya katılanların görüşme sorularına verdikleri yanıtlardan alt temalar oluşturulmuş ve katılımcıların görüşleri kodlanarak veriler sınıflandırılmıştır. Alt temaların hangi sıklıkta 
tekrar ettiği hesaplanarak frekans olarak tabloda sunulmuştur. Ayrıca katılımcıların görüşlerinden doğrudan alıntılar yaparak, temalar çarpıcı görüşler ile desteklenmiştir.

Araştırmanın güvenilirliğini ölçmek amacıyla veriler, araştırmacı ve bir uzman tarafindan incelenerek P (Uzlaşma yüzdesi) = Na (Görüş birliği) + Nd (Görüş ayrılı̆̆ı) x 100 (Miles \& Huberman 1994) formülü kullanılmış ve yapılan hesaplamalar sonucunda $\mathrm{P}=\% 90$ değeri bulunmuş ve araştırma güvenilir kabul edilmiştir.

\section{Bulgular ve Yorumlar}

Görüşme formunda yer alan sorular doğrultusunda başlıklar oluşturularak öğretmenlerin görüşlerine yer verilmiştir.

Tablo 1. Ara Disiplinlere İlişskin Öğretmen Görüşleri

\begin{tabular}{|c|c|}
\hline 1. Ara Disiplinlere İlişkin Öğretmen Görüşleri & $\mathbf{S}$ \\
\hline 1.1 Dersi zevkli hale getiriyor. & 1 \\
\hline 1.2 Matematiği günlük hayatla ilişkilendiriyor. & 4 \\
\hline 1.3 Öğrencilerin matematiğe karşı olan ilgisini artırarak dersi sevdiriyor. & 1 \\
\hline 1.4 Ara disiplinlere yönelik uygulamada yetersiz kalınıyor. & 1 \\
\hline 1.5 Matematiği somutlaştırmaya yardımcı olan araçlardır. & 2 \\
\hline $\begin{array}{l}\text { 1.6 Öğrencilerin matematiğin yaşamın bir parçası olduğunu ve farklı alanlarda da kullanıldığını fark } \\
\text { etmesini sağlıyor. }\end{array}$ & 1 \\
\hline 1.7 Öğrencilerin topluma faydalı bir birey olması açısından gereklidir. & 1 \\
\hline 1.8 Faydalıdır. & 2 \\
\hline $\begin{array}{l}\text { 1.9 Ara disiplinlerin dersin içine girmesi çok şart bir şey, ama bunun hangi yolla olacağ biraz somut hale } \\
\text { getirilmelidir. }\end{array}$ & 1 \\
\hline 1.10 Ara disiplinlerin kazandırılması matematik için biraz sıkıntılı oluyor. & 1 \\
\hline 1.11 Matematikle çok yakından alakalı olanları kullanıyorum. & 1 \\
\hline 1.12 Öğrencinin çok yönlü olarak (hem ders açısından hem de sosyal yönden) gelişimini sağlıyor. & 1 \\
\hline 1.13 Gereklidir. & 6 \\
\hline 1.14 Önemsiz ayrıntılarmış gibi göründüğü için amacına ne yazık ki ulaşamıyor. & 1 \\
\hline 1.15 Yeteri kadar kullanılamıyor. & 1 \\
\hline 1.16 Kalıcılığı sağliyor. & 1 \\
\hline 1.17 Ara disiplinler hakkında hizmet içi eğitim almadım, kısmen biliyorum. & 1 \\
\hline
\end{tabular}

Tablo 1'de görüldüğü gibi ara disiplinlerle ilgili en öne çıkan görüş ara disiplinlerin gerekli olduğu ve matematiği günlük hayatla ilişkilendirdiğidir. İkinci olarak öne çıkan görüş ise ara disiplinlerin faydalı olduğu ve matematiği soyut bir ders olmaktan çıkarıp somutlaştırdığıdır.

Ara disiplinlere ilişkin öğretmen görüşlerinin genel ve sınırlı olması öğretmenlerin ara disiplinlerin işleviyle ilgili yeterli bilgiye sahip olmadığının ve öğretme-öğrenme sürecinde yeterince işe koşmadıklarının göstergesi olabilir. Öğretmenlerin birçoğu yapılan görüşmeler esnasında bu durumu şu şekilde dile getirmiştir:

Ö8 numaralı öğretmenin görüşü:

“... Açıkçası ben hani şu kariyer bilincini geliştirme haricinde diğerlerini bilmiyordum, öncesinde sizinle görüşünceye kadar ...”.

Ö8 numaral1 öğretmenin görüşü:

“... Yani biz bunu ögrencilerimize yaptırlyoruz, ama ben bunun ara disiplin olduğunu bilmiyordum ...”. 
Ö12 numaralı öğretmenin görüşü:

“... İşte bir kere hizmet içi eğitim almadim kısmen biliyorum. Bildiğim kadarıyla cevaplıyorum ve kismen yeterince açık olduğunu düşünüyorum ...”.

Ö9 numaralı öğretmenin görüşü:

“... Şu ana kadar sizinle tanışmadan önce uyguluyorum, ama bu kadar kapsaml şey olduğu hakkında benim de bir bilgim yoktu. Sizin sayenizde biraz daha bilgim oldu ve bu konu hakkında kendimi biraz daha geliştirmeye çalışacağım ...”.

Ö7 numaralı öğretmenin görüşü:

“... ara disiplin deyince size de dedim zaten yabancl geliyor bu neymiş falan dedim, ama içindekilere baktıkça zaten okulda yaptı̆̆ımız uyguladiğımız, sadece derste değil, ders dışında da kutlamaları filan oluyor bir şeyler oluyor oralarda yaptık zaten yapıyorduk bunlar önemli mi önemli yani önemsiz değil tabi ki verilmesi lazım, ama hepsini matematik dersi içinde verebildiğimi veya verebileceğimi söyleyemem. Kısa kısa bahsedilebilir konu olarak, ama direkt dersin içeriği olarak vermek zor. Dersle birlikte dersin içine yerleştirmek zor bazılarını ...”.

Yukarda verilen öğretmen görüşlerinden hareketle, öğretmenlerin bazı ara disiplin kazanımlarını derslerinde işe koştukları veya okul içerisindeki çeşitli uygulamalarla kazandırmaya çalıştıkları fakat öğrencilere kazandırmaya çalıştıkları temanın ara disiplin olduğundan haberlerinin olmadığı sonucuna ulaşılabilir.

Ara disiplinlerin faydalı olduğunu düşünen öğretmenin görüşleri aşağıda verilmiştir:

Ö5 numaralı öğretmen:

“... tabi çocuğu topluma hazırlamak, toplumun değer yargılarını kazandırması açısından ve öğrendiği şeyleri kullanarak iyi bir birey olması açısından faydalı ...”.

Amacına ulaşamadığını düşünen öğretmenin görüşü şu şekildedir:

Ö10 numaralı öğretmen:

“... amacına tam olarak ulaşamadiğını düşünüyorum. SBS gibi çocuğun geleceğini belirlemek adına yapılan stnavlar ögrencinin ve velinin kafasını çok meşgul ediyor bu nedenle test, deneme gibi ögrenciyi sınava hazırlayan etkinlikler dikkat çekiyor. Bu nedenle ders içinde verilmek istenen ara disiplinler önemsiz ayrıntılarmış gibi göründüğü için amacına ne yazık ki ulaşamıyor ...”.

Matematikle yakından alakalı olanları kullandığını ifade eden öğretmenin görüşleri şu şekildedir:

Ö7 numaralı öğretmen:

“... Ara disiplinlere çok öncelik verdiğimi söyleyemem. Malum programin sıklşıklı̆̆l, sinav kaygisl, konuları yetiştirme, konularla ilgili daha fazla soru çözme gibi nedenlerden dolayı çok çok illa bu ara disiplini vereyim diye bir amacım yok, ama dersle daha yakından iliş̧kili olanları kullaniyoruz ...”. 
Dersi zevkli hale getirdiğini belirten öğretmenin görüşleri şu şekildedir:

Ö1 numaralı öğretmen:

“... Dersimde ara disiplinleri kullanıyorum. Ara disiplinler hakkındaki ögrencilerimin fikirlerine bakarsam, ögrencilerim gerçekten matematiği günlük hayatta uygulamaktan zevk allyorlar. Bir konuyu anlatırken onlarda daha kalıcı etkiler bırakıyor. Dersi zevkli hale getirdiğini düşünüyorum ...”.

Ara disiplinlerin dersin içine girmesi gerekli, ama bunun hangi yolla olacağı biraz somut hale getirilmeli diyen öğretmenin görüşleri şu şekildedir:

Ö6 numaralı öğretmen:

“... Bu ara disiplinlerin kazandırılması matematik için biraz sıkıntılı oluyor bir de hep kazandırılmalı diyorlar ama kimsenin somut bir çalışması yok... kendi branşımda zorlanıyorum. Soyut bir ders. Bazı konularda çok güzel ara disiplinler sağlanıyor gerçekten, ama bazı konularda sıfir. Ve bize bu konuda hiç bir açılklayıcı kaynak yok, çok sınırlı ...”.

Yukarıdaki öğretmenin görüşlerinden, öğretmenlerin ara disiplinlerin nasıl işe koşulacağ 1 konusunda yeterli bilgiye sahip olmadığı, ara disiplinlerle ilgili bilgilendirmeye ihtiyaç duydukları kanısına ulaşılabilir.

\section{Ara Disiplinlerin Önemi ve İșlevi}

Ara disiplinlerin amac1 ve önemi ile ilgili öğretmen görüşleri Tablo 2’ de verilmiştir:

Tablo 2. Ara Disiplinlerin Önemine ve İşlevine İlişkin Öğretmen Görüşleri

\begin{tabular}{|l|c|}
\hline 2. Ara Disiplinlerin Önemine ve İşlevine İlişkin Öğretmen Görüşleri & $\mathrm{S}$ \\
\hline 2.1 Önem & 6 \\
\hline 2.1.1 Önemlidir. & \\
\hline 2.2 İşlevler & 1 \\
\hline 2.2.1 Derslerde güncel haberleri almış ve uygulamış oluyoruz. & 1 \\
\hline 2.2.2 Günlük hayatta çocuk matematiği nasıl kullanacağını öğreniyor. & 1 \\
\hline 2.2.3 Çocukları konuya güdülüyor. & 1 \\
\hline 2.2.4 Derse ilgi uyandırıyor ve konunun daha iyi kavranılmasını sağlıyor. & 1 \\
\hline 2.2.5 Ara disiplinlerin amacını çok net sınırlayamadığım için fikrim yok. & 2 \\
\hline 2.2.6 Bilginin kalıcılığını sağlıyor. & 1 \\
\hline 2.2.7 Bazılarını dersle birlikte dersin içeriğine yerleştirmek zordur. & 1 \\
\hline 2.2.8 Programları tamamlaması açısından derslerin içerisinde verilmesi iyi oluyor. & 1 \\
\hline 2.2.9 Öğrencinin konuyu öğrenmedeki amacını açılıyor. & 1 \\
\hline 2.2.10 Konuların ne işe yarayacağını yanıtlıyor. & 1 \\
\hline 2.2.11 Öğrencilerin öğrendiklerini hayatın değişik alanlarında kullanabilmelerini sağlıyor. & 1 \\
\hline 2.2.12 Matematiği günlük hayatla ilişkilendirerek daha anlaşılır kılıyor. & \\
\hline
\end{tabular}

Yapılan görüşmelerde, öğretmenler arasında ara disiplinleri önemsiz bulan çıkmamıştır. Tablo 2'de de görüleceği gibi öğretmenlerin 6 tanesi ara disiplinlerin önemli olduğunu vurgulamıştır.

Öğrencilerin öğrendiklerini hayatın değişik alanlarında kullanabilmelerini sağlıyor diyen öğretmenin ara disiplinlerin amacına yönelik görüşü şu şekildedir:

Ö10 numaralı öğretmen: 
“... Öğrencilerimizin ögrrendiklerini sadece deneme sinavlarında uygulamak yerine hayatın değişik alanlarında karşılaştıklarında pratik, üretici, düşünme gücünü yansitabilmek olduğunu düşünüyorum ...”.

Konuların ne işe yarayacağını gösteriyor diyen öğretmenin ara disiplinlerin amacına yönelik görüşü şu şekildedir:

Ö9 numaralı öğretmenin görüşü:

“... Konularda sık sık "bu konu bizim ne işimize yarayacak öğretmenim” diyen ögrenciler oluyor. Sürekli bu sorularla karşılaşlyorum. Ara disiplinlerle bu soruları biraz daha yanitlamış oluyorum. Önemli olduğunu düşünüyorum ...”.

Bir başka öğretmenin ara disiplinlerin amacı hakkındaki görüşleri şu şekildedir:

Ö1 numaralı öğretmenin görüşü:

“... Ara disiplinlerin amacını tam olarak şöyle diyelim: günlük hayatta gerçekten çocuk matematiği kullanıyor ve nasıl kullandığını öğrenmesi açısından ya da işte ara disiplinlerle ne var, diyelim ki rüzgârın şiddetini ben ara disiplinlerle işliyorum ya da yangın olayları ormanlarda çıkan yangın olayları bunlarla çocuk sonuçta güncel haberleri almış oluyor ve uygulamıs oluyoruz derslerde ...”.

\section{Ara Disiplin Kazanımlarını Matematik Dersinin Kazanımlarıyla İlişsilendirme}

Ara disiplin kazanımlarını matematik dersinin kazanımlarıyla ilişkilendirme konusundaki öğretmen görüşleri Tablo 3'de verilmiştir:

Tablo 3. Ara Disiplin Kazanımlarını Matematik Dersinin Kazanımlarıyla İlişkilendirme

\begin{tabular}{|l|l|}
\hline 3. İlişkilendirme & $\mathrm{S}$ \\
\hline 3.1 ilişkilendirilebilir. & 8 \\
\hline 3.2 Kismen ilişkilendirilebiliyor. & 3 \\
\hline 3.3 ilişkilendirilemiyor. & 1 \\
\hline
\end{tabular}

Tablo 3'de de görüldüğü gibi 8 öğretmen matematik dersinin kazanımlarıyla ara disiplin kazanımlarının ilişkilendirilebileceğini ifade ederken, 3 öğretmen kısmen ilişkilendirilebileceğini (bazı ara disiplin dallarına ait kazanımlar ilişkilendirilebilirken, bazılarına ait kazanımlar ilişkilendirilemiyor), 1 öğretmen de ilişkilendirilemediğini belirtmiştir.

İlişkilendirmeyle ilgili bir öğretmenin görüşü şu şekildedir:

Ö9 numaralı öğretmenin görüşü:

“... istatistik olursa olabilir grafiklerde yapabiliriz yani hangi ne sebeple çıkmuş işte piknik türü işte diğer bilinçsizlik şu sıralansa grafik çizersek onlar rahatllkla istatistikle yapabiliriz. Faiz konusu var mesela, faiz bizim 7. sınıfta ayrı bir konumuz onu çok rahat verebiliriz. Parasını uygun biçimde önceliklerini belirleyerek, bilinçli tüketim aritmetiği var konularımızda zaten bunun üzerinde çokça duruyoruz. Hangisini alması daha uygun olur, hangisini öncelikle alması gerekiyor, hangisi onun için daha uygun daha ucuza geliyor, bunlar zaten bilinçli tüketim aritmetiğinde veriliyor. Mesela karar verme sürecinde ortaya çıkabilecek çeşitli 
alternatifleri belirler, rehberlik ve psikolojik ara disiplinine ait kazanim, genelde rehberlik dersinde yapabiliriz de matematikte biraz uzak düşmüs oluyor ...”.

Başka bir öğretmenin görüşü şu şekildedir:

Ö8 numaralı öğretmenin görüşü:

“... Afetten korunma var ya onu ilişkilendirmek biraz zor olur sonuçta tabi ilişkilendirilebilir uğraşırsak, ama biz zaten bilinçli olmadan uyguladiğımız için bu şeyleri mesela ne diyor heyelan oluşumundaki nedenleri sorgular ben hiç böyle bir şeye gerek duymuyorum çocuklara ögretmekte. Ya da mesela ne diyor hareket ve spor malzemelerinin yerlerini sıralar diyor, yani ben bunlara ihtiyaç duymuyorum açıkçası matematik dersinde. Ama belki başka derslerde yapıyorlardır böyle şeyler ...”.

Bir diğer öğretmenin söyledikleri aşağıda verilmiştir:

Ö7 numaralı öğretmenin görüşü:

“... Yani ilişskilendirilebilir ama.... Zamandan da tasarruf yapmamız gerektiği için çok da iliş̧kilendiremiyoruz yani ...”.

Ö6 numaralı öğretmenin görüşü:

“... İlişkilendiriliyor aslında... Mesela atıyorum matematikte benim hiç yapamayacağım engellilere yönelik çevresel düzenlemeler ya da engellilerle ilgili bilinç sağlamak. Ben onu ne zaman yapabilirim eğim konusunu görürken çok olsa derim ki engelli birisinin tırmanacă̆ eğim yapın kaldırıma onu diyebilirim, ancak yani bunların yüzde yüz benim dersimde ilişkilendirilmesi biraz zor, ama yapılmaz mi yapılır bunlar çok uçuk şeyler değil ...”.

Ö5 numaralı öğretmenin görüşü:

“... Tabi yani şimdi bazı konularda ilişkilendirmek kolay olduğu gibi bazı konularda zor oluyor fakat genel olarak ara disiplin kuralları matematik dersiyle birebir ilişkilendirilebilir; çünkü günlük hayatta günlük yaşamda matematiğin kullanılmadı̆̆ bir alan ve yer yok.... Dolayısıyla hayatla iç içe olduğu için de kolaylıkla ilişkilendirilebilir diye düşünüyorum ...”.

Ö11 numaralı öğretmenin görüşü:

"Yani elimizden geldiğince ilişkilendirmeye çalışıyoruz. Ama dediğim gibi zamanımı kısıtlı onun dışında müfredat yoğun ondan dolayı bazı konuları basit bir şekilde geçmek zorunda kalıyoruz; çünkü müfredatımız yoğun yetiştirmek zorundayız ki ucu ucuna gelmiş durumda hatta sinavimız var biliyorsunuz SBS sinavi. SBS sinavinın tarihinden 2 hafta sonraya kadar konumuz var, bizim ki onu ondan önce bitirmek zorundayı bu tarz sorunlardan dolayl yeterince iliş̧kilendirilemediğini düşünüyorum ara disiplinlerin ...”.

Yine benzer şekilde bir başka öğretmenin görüşü şu şekildedir: 
Ö9 numaralı öğretmen:

"Tabi ki bizim sorunumuz burada süre. Süre olduktan sonra bence bunların kazandırılabileceğine inanıyorum; ama süreden dolayı ki ben de pek fazla değinemiyorum belki yani dersin içine pek fazla katamamışımdır. Ama diğer türlü süre sikıntısı olmazsa kazandırılabileceğine inaniyorum ...”.

İlişkilendirilemediğini düşünen öğretmenin görüşü de şu şekildedir:

Ö3 numaralı öğretmen:

"Programda yer alan ara disiplin kavramlarını matematik programiyla çok ilişkilendiremiyorum ...”.

\section{Ara Disiplinlere İlişkin Öğretme-Öğrenme Ortamları Tasarlama}

Ara disiplinlere ilişkin öğretme-öğrenme ortamları tasarlamaya ilişkin öğretmen görüşleri Tablo 4'te verilmiştir:

Tablo 4. Ara Disiplinlere İlişkin Öğretme-Öğrenme Ortamları Tasarlama

\begin{tabular}{|l|l|}
\hline 4. Ara Disiplinlere İlişkin Öğretme-Öğrenme Ortamları Tasarlama & $\mathrm{S}$ \\
\hline 4.1 Ara disiplinlere ilişkin Öğretme-Öğrenme ortamları tasarlıyorum. & 1 \\
\hline 4.2 Ara disiplinlere ilişkin Öğretme-Öğrenme ortamları tasarlamıyorum. & 11 \\
\hline
\end{tabular}

Tablo 4'de de görüldüğü gibi yalnızca 1 öğretmen ara disiplinlere ilişkin öğretme-öğrenme ortamları hazırlama sorusuna evet yanıtını vermiştir. Öğretmenin söyledikleri aşağıda verilmiştir:

Ö9 numaralı öğretmenin görüşü:

"Tabi ki oluşturuyoruz. Yine ögrencilerin fikirlerini alarak bir şekilde bir tartışma ortamı oluşturarak onları da matematikteki o konunun günlük hayatla ilişkilendirilmesi onların o şekilde kazandırılmasını sağlıyoruz ...”.

Diğer bir öğretmenlerin görüşleri de şu şekildedir:

Ö11 numaralı öğretmen:

"Yani önceden bir tasarlama olmuyor ama doğaçlama olarak farkında olmadan bu alternatiflerin bazılarını kullaniyoruz yani ama özellikle daha önceden bunu yapayım böyle olursa şöyle olur gibi yapmıyoruz ki yani mutlaka yapılmal bizim tek amacımı hani sinav kazandırmak olmamalı iyi bir birey yetiştirmek bence daha da önce gelmeli. Eğitim kesinlikle içinde olmalı. Bizim şu an yaptı̆̆ımızı yüzdeye vuracak olursak büyük kısmı sınav kazandırmaya yönelik maalesef. Yine buna verilecek çok fazla da örnek var. Yani çok iyi okullarda okuyup da şu anda çevresine ya da devlete zarar veren çok insan var gözümüzün önünde maalesef. Bence olmall yapilmall yani ...”.

Bir diğer öğretmenin görüşü ise şu şekildedir:

Ö8 numaralı öğretmen:

"Yok, yani özel olarak zaten hani ara disiplinleri de katayım ders planıma diye bir düzenleme yapmıyorum yani. Çoğu zaman söylediğim gibi 
farkinda da olmuyoruz ...”.

Bir başka öğretmenin görüşü şöyledir:

Ö5 numaralı öğretmen:

“... Derslerin girişinde sözel olarak olsun çocuklara hani öğrenecekleri konuya girerken hem de dikkatlerini toplamak açısından derse hazırlamak açısından hayatta nerde kullanılabileceğini nerde ne işe yarayacağını bunu ögretiyoruz derse ne gibi faydaları olacağından bahsediyoruz derse giriş kısmında. Ekstra ayriyeten bir çalışma yapmıyoruz ...”.

\section{Ara Disiplinlere Yönelik Uygulamalara Yer Verme}

Tablo 5 'te öğretmenlerin derslerinde daha çok ve daha az işe koştukları ara disiplinler öğretmen sayılarına göre verilmiştir.

Tablo 5. Ara Disiplinlerin Öğretmenlerce İşe Koşulma Durumları

\begin{tabular}{|l|c|c|}
\hline $\begin{array}{l}\text { 5. Ara Disiplinlerin Öğretmenlerce İşe } \\
\text { Koşulma Durumları }\end{array}$ & $\begin{array}{c}\text { Daha Sık Isşe } \\
\text { Koşulanlar (f) }\end{array}$ & $\begin{array}{c}\text { Daha Az İşe } \\
\text { Koşulanlar (f) }\end{array}$ \\
\hline 5.1 Afetten Korunma ve Güvenli Yaşam & 1 & 2 \\
\hline 5.2 Sağlık Kültürü & 2 & 1 \\
\hline 5.3 İnsan Hakları ve Vatandaşlık & 5 & 1 \\
\hline 5.4 Girişimcilik & 7 & 1 \\
\hline 5.5 Kariyer Bilinci Geliştirme & 5 & 2 \\
\hline 5.6 Rehberlik ve Psikolojik Danışma & 2 & \\
\hline 5.7 Spor Kültürü ve Olimpik Eğitim & 3 & 1 \\
\hline 5.8 Özel Eğitim & & \\
\hline
\end{tabular}

Tablo 5' den de görüldüğü gibi 7 öğretmen girişimcilik ara disiplinini derslerinde daha çok kullandıklarını ifade etmiştir. 5 öğretmen de, kariyer bilinci geliştirme ve insan hakları ve vatandaşlık ara disiplinlerini derslerinde daha çok kullandıklarını belirterek bu ara disiplinlerin girişimcilikten sonra en çok işe koşulan ikinci ara disiplin olmalarını sağlamıştır. Öğretmenlerin görüşlerine göre afetten korunma ve güvenli yaşam ile özel eğitim ara disiplinleri derslerinde en az işe koştukları ara disiplinlerdir. Bir öğretmen ara disiplinleri kazandırmaya yönelik özel bir çaba harcamadığını belirtmiştir.

Ö5 numaralı öğretmenin görüşü:

“... gerekli çalışmaları sözel olarak yapıyoruz; ama bir plan çerçevesinde yapamıyoruz; çünkü müfredatta 40 dakikalık ders esnasında zaten buna ekstra bir zaman ayırmamız mümkün değil”.

Ö9 numaralı öğretmenin görüşü:

"Bu girişimcilik. Okulumuzda bir proje var mesela bununla ilgili, matematik ile ilgili bir proje. Askıda soru var. Öğrencilerin kendilerinin mesela soru asmaların daha sonra yine kendilerinin cevaplandirmaları. Bir şekilde girişimciliği pekiştirmeye çalışlyoruz orda. O tarz yine 
okulumuzda uygulanan bir proje var, ögrencilerin birbirine yardım etmesi birbirleriyle çalı̧̧ma ortamları var beraber çalışıyorlar o şekilde de girişimcilik ara disiplinini kazandırmaya çalışlyoruz. Bir şekilde okul içinde kazandirlliyor. Milli eğitim tarafindan da bu projelere çok destek var. Onlar da bu konuda gereksinim duyuyorlar uygulanmasinı istiyorlar kesinlikle. Biz de elimizden geldiği kadar uygulamaya çalışıoruz. Proje çalışmalarına katılmaya çalışıyoruz. 'Bu Benim Eserim' Mili Eğitim tarafindan Türkiye genelinde yapılan bu tarz inşallah ilerde başarımız olur".

Ö11 numaralı öğretmenin görüşü:

“... işte öğrenciler hep sinava yönelik olduğu için bunlar hani bir kısmı günlük hayatla ilişkilendirmek istiyorlar ama bir kısmı da hani şey diyor ya ne gereği var bunun bu kadar uzatmayalım direkt soru çözelim daha fazla soru görelim işte formül alalım yani o amaçla baklyorlar. Matematik olduğu zaman direkt akıllarına sinav kaygısl, maalesef ögretim geliyor onların aklina. Bu yönde sorun yaşlyoruz maalesef. Hani kendileriyle de çelişiyorlar. Aynı ögrenci şey soruyor bunu nerde kullanacağım günlük hayatta ne gereği var derken bir sonraki derste işte hocam bu kadar uzatmaya ne gerek var bunları atlasak da direkt formüllere geçsek. Onlar da bir çelişki içerisindeler maalesef'.

Yukarıdaki öğretmenin görüşlerinden öğrencilerin SBS sınav kaygısı taşıdıkları ve bu kaygıyla öğretmenlerini eğitim programının kazanımlarını kazandırmaya yönelik değil de sınavda yüksek puan alma hedefli ders işlemeye ittikleri sonucuna ulaşılabilir. Bu durum öğretmenlerin derslerinde neden ara disiplinleri işe koşamadıklarının bir göstergesi olarak düşünülebilir.

\section{Ara Disiplinlerin Kazandırılmasına İlişkin Yapılan Uygulamalarda Kullanılan Öğretim Illke ve Yöntemleri}

Öğretmenlerin ara disiplinlerin kazandırılmasına ilişkin yapılan uygulamalarda kullandıkları öğretim yöntem ve teknikleri Tablo 6' da verilmiştir:

Tablo 6. Ara Disiplinlerin Kazandırılmasına İlişkin Yapılan Uygulamalarda Kullanılan Öğretim İlke ve Yöntemleri

\begin{tabular}{|l|c|}
\hline 6. Kullanılan Öğretim İlke ve Yöntemleri & S \\
\hline 6.1 Ders Konusunu Anlatırken Kullandığım Yöntemlerle Aynı & 6 \\
\hline 6.2 Buluş Yoluyla & 4 \\
\hline 6.3 Etkinliklerle & 2 \\
\hline 6.4 Anlatım & 3 \\
\hline 6.5 Soru Cevap & 4 \\
\hline 6.6 Problem Çözme & 1 \\
\hline 6.7 Beyin Fırtınası & 4 \\
\hline 6.8 Tartı̧̧ma & 3 \\
\hline 6.9 Çalışma Yaprağı Hazırlama & 1 \\
\hline 6.10 Eğlenceli Oyun Yoluyla & 2 \\
\hline 6.11 Drama & 1 \\
\hline
\end{tabular}


Tablo 6'dan da görüldüğü gibi öğretmenlerin çoğu ara disiplinleri kazandırmaya yönelik özel yöntem ve teknikleri kullanmadıklarını belirtmişlerdir (Ders konusunu anlatırken kullandığım yöntemlerle aynı). Bunun dışında çizelgede yer alan öğretim yöntem ve tekniklerini kullandığını belirten öğretmenlerden bunları nasıl kullandığına dair herhangi bir açıklama yapan olmamıştır.

Bir öğretmenin konuyla ilgili görüşü şu şekildedir:

Ö11 numaralı öğretmen:

“... şimdi zaman sıkıntımız olduğu için şu andaki eğitim sistemi öğrenci merkezli olması gerekmesine rağmen hala ögretmen merkezli ilerliyoruz. Ben genelde anlatıyorum. Yine aynen ögretmen merkezli devam edip anlatiyorum onlar dinliyorlar".

\section{Uygulamada Karşılaşılan Sorunlar}

Öğretmenlerin uygulamada karşılaştıkları sorunlara ilişkin cevapları şu şekildedir: Süre sıkıntısı, fiziksel ortam, kazanımların kılavuz kitapta matematik dersiyle ilişkisinin yeterince açıklanmamış olması, materyal eksikliği, öğrencilerdeki matematiğe karşı olan önyargı, veliler, iletişim, aile problemleri olan öğrenciler, öğretmenlerde konuları yetiştirme kaygısı, öğrencilerdeki sınav kaygısı, ara disiplinlerle ilgili yeterli bilgiye sahip olmama, konuyla ilgili açıklayıcı kaynağın olmaması, programın yoğun olması, programın isteğiyle öğrencilerin isteğinin farklı olması ve öğretmenlerin arada kalması, etkinliklerin bazılarının gereksiz olması.

\section{Uygulama Karşılaşılan Sorunlara İlişkin Önerilen Çözüm Yolları}

Öğretmenler karşılaşılan sorunlara ilişkin şunları önermişlerdir: Konular eksiltilebilir, programın yoğunluğu azaltılabilir, matematik dersinin saati artırılabilir, öğretmen kılavuz kitapları daha bilgilendirici hale getirilebilir, hizmet içi eğitim verilebilir, programda gerekli değişiklikler yapılabilir, açıklayıcı kaynaklar olabilir.

\section{Ara Disiplinlerin Kazandırılıp Kazandırılmadığını Belirlemeye İlişkin Yapılan Ölçme- Değerlendirme Etkinlikleri}

Öğretmenlerin tamamı ara disiplinlerin kazandırılıp kazandırılmadığını belirlemeye ilişkin herhangi bir ölçme değerlendirme uygulaması yapmadığını belirtmiştir. Bununla birlikte öğretmenlerin çoğu öğrencilerinin davranışlarını gözlemleyerek kazanıp kazanmadıklarının belirlenebileceğini belirtmişlerdir. Bir öğretmen yazılıda günlük hayattan mutlaka bir soru sorduğunu söylemiştir. Bir öğretmen matematikle ilgili olanların test sorusuyla belirlenebileceğini söylerken; bir öğretmen de konuşarak, öğrenciyle sohbet ederek belirleyebileceğini söylemiştir.

\section{Öğrencilerin Daha Fazla İlgisini Çeken Ara Disiplin Dalları}

Öğretmenlerin derste edindikleri izlenimlere dayanarak öğrencilerinin daha çok ilgisini çeken ara disiplin dalları Tablo 7'de verilmiştir.

Tablo 7. Öğrencilerin Daha Fazla İlgisini Çeken Ara Disiplin Dalları

\begin{tabular}{|l|c|}
\hline 7. Öğrencilerin Daha Fazla İlgisini Çeken Ara Disiplin Dalları & S \\
\hline 7.1 Afetten Korunma ve Güvenli Yaşam & 1 \\
\hline 7.2 Sağlık Kültürü & 2 \\
\hline 7.3 Girişimcilik & 6 \\
\hline 7.4 Kariyer Bilinci Geliştirme & 4 \\
\hline 7.5 Rehberlik ve Psikolojik Danışma & 3 \\
\hline
\end{tabular}




\begin{tabular}{|l|l|}
\hline 7.6 Spor Kültürü ve Olimpik Eğitim & 5 \\
\hline 7.7 İnsan Hakları ve Vatandaşlık & 1 \\
\hline
\end{tabular}

Öğrencilerin en çok ilgisini çeken ara disiplin dalı Tablo 7' de de görüldüğü gibi girişimciliktir. Onu sırayla spor kültürü ve olimpik eğitim ile kariyer bilinci geliştirme takip etmektedir.

Ö6 numaralı öğretmenin görüşü:

"Valla işte bir çocuğun neye ilgisi varsa o konuya ilgisini çekmektedir. Mesela spor etkinlikleri faaliyetleri çok seven bir çocuk sen müzikle ya da resimle ilgili ne kadar ilişki kurarsan kur spor alanındakini anllyor hani bir çocuğun o biraz kişisel ilgisine zekâ yapısına bağlı yani ”.

\section{Öğretmenlerce Gereksiz Bulunan Ara Disiplin Dalları}

Görüşme yapılan öğretmenlerin nerdeyse tamamının (10 öğretmen) gereksiz bulduğu ve programdan çıkarılmasını istediği bir ara disiplin dalı olmamıştır.

Ö8 numaralı öğretmenin görüşü:

“... Gereksiz olduğunu düşündüğüm bir şey yok, ama spor kültürü ve olimpik eğitim bu biraz fazlalık olabilir belki çünkü spor aletlerinin sıralanmasıyla matematiğin kendi amaçları arasında bir ilişki olamaz”.

Ö9 numaralı öğretmenin görüşü::

“ Mutlaka hepsini bir bilen bildiklerinden dolayı koymuştur, ama hani ne bilim insan haklart ve vatandaşlık hani sosyal bilimler dersi ile daha alakalı olduğu için mi düşündüm şu an ama. Şuna inantrım matematiği biz kendimiz ortaya koymadı doğada vardl yani bir şekilde gerekli eğitim verilirse yani hepsinin belki çok fazla olmayabilir, ama belirli bir düzeyde verilebileceğine inanıyorum”.

Ö7 numaralı öğretmenin görüşü:

"Çıkarılsın diyebileceğim yok hani bunlar da öğrenmeleri gerekiyor sonuçta çocukların. Hani matematiğin içinde bunlar verebiliyor muyuz o tartışılır, ama matematiğin içinde de olmasa da bir şekilde verilmesi lazım yani bunların yine de çocuklara".

Bütün bunlardan öğretmenlerin çoğunun ara disiplinleri önemli buldukları ve bir şekilde kazandırılmasını istedikleri sonucuna ulaşılabilir.

\section{Ara Disiplin Olarak Programa Eklenmesi Düșünülen Konular, Temalar}

Öğretmenlerin ara disiplin olarak programa yerleştirilmesini istedikleri konular; davranış eğitimi, sigara ve eroin kullanımı, paylaşımcılık, ahlak eğitimi, sosyal ilişkiler, bilinçli kredi kartı kullanımı, görsel ve işitsel sanattır.

Ö8 numaralı öğretmenin görüşü:

“... yani ögrrenciler hem birbirine karşı saygısı hem öğretmelerine karşı saygısızlar, hani bununla ilgili belki bir şeyler eklenebilir belki, ama matematikle nasıl bağlanır onu bilemem yani. Ahlak eğitimiyle ilgili bir şey eklenebilir. Ya da insanlar arası ilişkileri teşvik eden kazanımlar da konulabilir". 
Ö7 numaralı öğretmenin görüşü:

"Ülkemizde insanların kredi kartları açısından çok borçlu olduğunu düşünürsek, insanlar harcamalarında kredi kartlarına yükleniyor ve para harcamayı bilmiyorlar; o açıdan biraz daha verilebilir bir şeyler çocuklara. Öğrenciler de söylüyor kendi ailelerinden mesela kredi kartı borcu çok şöyle kredi ald kapatmak için. Bunlar kazandırılmalı çocuklara ilerde onlar da aynı hataları yapmamaları için".

Ö2 numaralı öğretmenin görüşü:

“... insanların birbiriyle olan davranışlarıly ilgili ara disiplin olabilir. Çünkü ... Eğitim biraz geri planda kaldı çocukların eğitilmesiyle ilgili ara disiplinlere yer verilebilir diye düşünüyorum. Çocukları burada tek işi matematikte toplama çıkarma öğrenmek değil tabi ki ...”.

\section{Sonuç ve Tartışma}

$\mathrm{Bu}$ araştırma ile öğretmenlerin ara disiplinler konusunda çok az ve sınırlı bilgiye sahip olduğu ve ara disiplinler konusunda bilgilendirmeye ihtiyaç duyduğu sonucuna ulaşılmıştır. Bu sonuç, diğer araştırma sonuçlarıyla da (Gözütok \& Alkın 2008; Ermiş 2008; Taş 2010) örtüşmektedir. Öğretmenlerin ara disiplinlerin programdaki işlevlerine ilişkin görüşlerinin sınırlı olmasının sebebi programda ara disiplinlerin tanımına, işlevine, rolüne ilişkin yeterli bilginin verilmemesinden kaynaklanabilir (Gözütok \& Alkın 2008; Ermiş 2008).

Araştırma ile ulaşılan bir diğer sonuç; öğretmenlerin ara disiplinlerin işlevini tam olarak bilmediğidir. Ara disiplinler bazı konuları yaşamla ilişkilendirerek kullanım alanlarını gösterse de programa sadece bu amaçla yerleştirilmemiştir. Naval ve diğerleri'nin (2003) belirttiği gibi ara disiplin temaları bilginin belli bir alana (disipline) hapsedilmesini önlemekte, sosyal taleplere veya konulara cevap vererek okulun sosyalleştirme fonksiyonunu güçlendirmekte ve eğitimin nihai amacı olan insanın her yönden gelişimini hedeflemektedir.

Öğretmenlerin çoğu, ara disiplinlerin önemli ve gerekli olduğunu düşünmektedir. Çünkü ara disiplinler öğrencilerin bilişsel, duygusal ve sosyal yönlerini bir bütün olarak geliştirmektedir (Gözütok \& Alkın 2008). Ara disiplinler öğrencilerin kendini bilme ve öz saygılarını geliştirmelerine olanak sağlamaktadır (DENI 2008).

Öğretmenlerin çoğunun ara disiplin dallarına ait kazanımların matematik dersine ait kazanımlarla ilişkilendirilebileceğini düşündüğü, ancak çeşitli sebeplerden dolayı öğretme öğrenme sürecinde ilişkilendirme adına gerekli çabayı göstermedikleri sonucuna ulaşılmıştır. Bunun en önemli sebebi ilişkilendirmelerin nasıl yapılacağı konusunun açık olmaması olabilir (ERG 2005). Bunun yanında, öğretmenlerin görüşlerinden de görüleceği gibi derslerini öğrencilerini ulusal sınava hazırlamaya yönelik işlemeleri olabilir.

Öğretmenler programın yoğun olması, zaman sıkıntıs1, öğrencilerdeki sınav kaygıs1 ve programı yetiştirme telaşı gibi sebeplerden dolayı ara disiplinleri derslerinde çok fazla işe koşamadıklarını belirtmişlerdir. Program hafifletilirse, süre sıkıntısı ortadan kaldırılırsa ve ara disiplinler konusunda gerekli bilgilendirmeler yapılırsa derslerinde ara disiplinleri işe koşabileceklerini söylemişlerdir.

Öğretmenler öğrencilerinin ara disiplin kazanımlarını kazanıp kazanmadığını belirleme adına özel ölçme değerlendirme uygulamaları yapmamaktadır. Genel olarak öğretmenler öğrencilerinin davranışlarını gözlemleyerek kazanıp kazanmadıklarını belirlemeye çalıştıklarını ifade etmişlerdir.

Araştırmadan elde edilen bulgular doğrultusunda uygulamaya ve yapılabilecek yeni araştırma- 
lara yönelik şu önerilerde bulunulabilir:

Programın uygulayıcısı olan öğretmenlere ara disiplinler konusunda hizmet içi eğitim verilmelidir. Öğretim Programında ve öğretmen klavuz kitabında ara disiplinlere yönelik yeterli açıklama ve yönergelere yer verilmelidir.

Ara disiplinlere yönelik yeni araştırmalar farklı şehir, farklı çalışma grubu, farklı dersler ve farklı öğretim düzeyleri seçilerek gerçekleştirilebilir.

\section{KAYNAKÇA}

Akyol Ş. (2011). Illköğretim II. Kademe Matematik Dersi Öğretim Programında Yer Alan Ara Disiplinlere Yönelik Öğretmen Görüşleri. Yüksek Lisans Tezi. Hacettepe Üniversitesi, Sosyal Bilimler Enstitüsü. Ankara 2011.

Coşkun-Diker Y. \& Demirel M. (2009). "Proje Tabanlı Öğrenme İle Desteklenen Disiplinler Arası Öğretim Yaklaşımına İlişkin Bir Durum Çalışması”. 1. Uluslararası Eğitim Araştırmaları Kongresi Tam Metin Bildiriler Kitabl (2009) 1-22.

DENI (Department of Education), (2008). Educational (Cross-Curricular) Themes. Kaynak: http://www.deni.gov.uk/cct_1.pdf. Erişim tarihi: 10.05.2011.

ERG (Eğitim Reformu Girişimi), (2005). Yeni Öğretim Programlarını İnceleme ve Değerlendirme Raporu. Kaynak: ilkogretim-online.org.tr/vol5say1/yenimufredat_raporu\%5B1\%5D.pdf. Erişim tarihi: 10.04.2011.

Ermiş S. (2008). Sosyal Bilgiler Dersindeki Ara Disiplinlerin Sinıf İçi Uygulamalarına Yönelik Öğretmen Görüşleri. Yüksek Lisans Tezi. Abant İzzet Baysal Üniversitesi, Sosyal Bilimler Enstitüsü. Bolu 2008.

Gözütok F. D. \& Alkın S. (2008). "İlköğretim Öğretmenlerinin Programdaki Ara Disiplin Yaklaşımına İlişkin Görüşleri”. Proceedings of International Conference on Educational Sciences 2 (2008) 83985, 23-25 Haziran 2008.

MEB (2009). “6-8 Sınıflar Matematik Dersi Öğretim Programı”. Kaynak: http://ttkb.meb.gov.tr. Erişim tarihi: 23.04.2014.

Miles M. \& Huberman A. (1994). Qualitative Data Analysis: An Expanded Source Book. Thousand Oakes, California 1994.

Naval C., Print M. \& Iriarte C. (2003). "Civic Education in Spain: A Critical Review of Policy". http://www.jsse.org/2003-2/spain_naval.htm. Erişim tarihi: 10.03.2011.

Taş D. İ. (2010). 2005 İlkögrretim Programının Hazırlanmasında Görev Alan Ara Disiplinler Komisyonu Üyelerinin ve Sinı Öğgretmenlerinin Ara Disiplin Yaklaşımı Konusundaki Bilgi Durumu ve Görüşlerinin Belirlenmesi. Yayımlanmamış Yüksek Lisans Tezi. Ankara Üniversitesi, Eğitim Bilimleri Enstitüsü. Ankara 2010.

Yağcı E., Demirel M. \& Tatar Ö. (2009). "Fen ve Teknoloji Dersi Öğretim Programının Bütünleştirilmiş Program Yaklaşımı Açısından Değerlendirilmesi”. Uluslararası 5. Balkan Eğitim ve Bilim Kongresi. Günümüzde Balkanlarda Eğitim Kongre Tam Metin Kitabl (2009) 148-152.

Yıldırım A. \& Şimşek H. (2008). Sosyal Bilimlerde Nitel Araştırma Yöntemleri. Ankara 2008. 